\title{
Exploring Vertebrate Behavior at Mesocarnivore Carcass Sites: Implications for Non-Trophic Parasite Transmission
}

\section{Gonzálvez Moisés}

University of Murcia: Universidad de Murcia

Carlos Martínez-Carrasco ( $\nabla$ cmcpleit@um.es)

Facultad de Veterinaria, Universidad de Murcia https://orcid.org/0000-0002-8742-0109

\section{Moleón Marcos}

University of Granada: Universidad de Granada

\section{Research Article}

Keywords: Carnivore, Carrion, Non-trophically transmitted parasites, Sarcoptes scabiei, Scavenger, Wildlife

Posted Date: May 7th, 2021

DOI: https://doi.org/10.21203/rs.3.rs-488230/v1

License: (c) (i) This work is licensed under a Creative Commons Attribution 4.0 International License. Read Full License 


\section{Abstract}

The spatiotemporal distribution of parasites in ecosystems is heterogeneous. High infection risk is often associated with aggregations of animals around attractive resources. Here, we explore the behavior of potential hosts of non-trophically transmitted parasites at mesocarnivore carcass sites. We used videos recorded by camera traps at 56 red fox (Vulpes vulpes) carcasses and 10 carcasses of other wild carnivore species in three areas of southeastern Spain. In general, scavenging species, especially wild canids, mustelids and viverrids that display rubbing behavior, were more exposed to infection risk at carnivore carcass sites than non-scavenging and domestic species. The red fox was the species that most frequently contacted carcasses and marked and rubbed carcass sites. Foxes contacted heterospecific carcasses more frequently and earlier than conspecific ones, and close contact was more frequently observed at heterospecific carcasses. Thus, foxes seemed to avoid contacting carcasses in those periods and at carcass types of maximum risk of acquiring parasites. Overall, our results suggest that infection risk at carnivore carcass sites may take place mainly for visitor-carcass contact or contact with feces and urine rather than direct contact between visitors. Moreover, contact events between scavengers and carnivore carcasses are far more frequent than consumption events, which indicates that scavenger behavior is more constrained by the risk of acquiring meat-borne parasites than nontrophically transmitted parasites. This study contributes to filling key gaps in understanding the role of carrion in the landscape of disgust, which may be especially relevant in the current global context of emerging and re-emerging pathogens.

\section{Introduction}

Pathogen distribution is spatially and temporally heterogeneous, so epidemiological landscapes frequently consist of hotspots for transmission risk within a matrix of area with reduced or even no exposure to parasites (Bousema et al. 2012; Buck et al. 2018; Weinstein et al. 2018a). Infection risk hotspots may be driven by the presence of attractive resources that favor aggregation of animals, such as water points and food-rich patches, or by specific sites where pathogens are more like to accumulate, such as latrines (Buck et al. 2018; Weinstein et al. 2018a, 2018b). Epidemiological risk may also be increased by species-specific behaviors, such as social interactions between individuals of gregarious species or family groups, or during certain times of year, such as the rutting season (Altizer et al. 2003; Patterson and Ruckstuhl 2013; Ezenwa et al. 2016). Infection risk also depends on the diversity of susceptible and alternative hosts in the environment (Johnson and Thieltges 2010). In this context, when food resources and other points of attraction are apparently infected, hosts must weigh the perceived infection risk against foraging gains and other benefits (Weinstein et al. 2018b). Understanding host behavioral responses to potential risk of infection associated with food resources is relevant from an ecological and evolutionary perspective, but also provides a solid basis for better interpreting the epidemiological risk factors that favor the transmission of pathogens in the wild (Hart 1990; Kuris 2003; Penczykowski et al. 2015; Stockmaier et al. 2021).

Carcasses are a paradigmatic example of a food resource that may be regarded as hotspots for both trophically and non-trophically transmitted pathogens (Turner et al. 2014; Dmitric et al. 2017; Moleón and Sánchez-Zapata 2021). This nutrient-rich resource attracts many scavengers in all ecosystems (DeVault et al. 2003; Beasley et al. 2012; Mateo-Tomás et al. 2015; Sebastián-González et al. 2019), leading to concentrations around carcasses of up to hundreds of individuals in the case of vultures (Donázar 1993). In the absence of vultures, which are very efficient carrion consumers, many opportunistic or facultative scavengers, such as mammalian mesocarnivores, may readily access carrion (Morales-Reyes et al. 2017). In these conditions, parasite transmission may occur not only from the carcass to the scavenger (Byrom et al. 2015; Straub et al. 2015), but also among different scavengers that co-occur at carcass sites (Ogada et al. 2012; Borchering et al. 2017). Moreover, the dead animal can be a source of pathogens for non-scavenging species that approach the carcass without the intention of eating it, for other species that contact the carcass with the aim of ingesting the necrophagous invertebrates found on it, as well as for animal species that use the carcass for non-trophic purposes, such as marking behavior and taking material for nest construction (Moleón and Sánchez-Zapata 2016, 2021).

Carcasses are normally an ephemeral resource (DeVault et al. 2003; Barton et al. 2013). However, not all of them have the same duration in the environment. Carcasses of carnivorous species generally persist longer than those of herbivorous species (Selva et al. 2005; Olson et al. 2016; Moleón et al. 2017, 2020). Field observations indicate that carnivorous species avoid feeding on carcasses of phylogenetically related species, especially on conspecific carcasses, probably due to the increased risk of acquiring species-specific meat-borne parasites (Hart 2011; Moleón et al. 2017). Therefore, the opportunities for contact between carcasses and the visiting vertebrate species, as well as between the latter, are higher in the case of carnivore carcasses. Consequently, the possibility that visiting species may be infected through this type of carcass, even if not consumed, may also increase. Thus, carnivore carcasses are an excellent model to study host behavior around carcasses and how this behavior changes with time; in this way, it could be inferred whether this behavior carries a risk of acquiring non-trophically transmitted parasites. However, fine-grained behavioral studies about the risk associated with carcass sites are largely lacking, particularly for carnivore carrion (Moleón and Sánchez-Zapata 2021).

In the case of mammalian carnivores, non-trophically transmitted pathogens include a wide range of parasites, fungus, bacteria and viruses. These pathogens have characteristics that largely condition their virulence and transmission, such as survival time in the environment of the 
infective stages, within-host replication rate, pathogen infectivity, the route of infection, the number of host species that are susceptible, and the life cycle they present (Poulin 2007; Alizon and Michalakis 2015; Acevedo et al. 2019; Brouwer et al. 2019;). The persistence outside the host of infective stages can vary from a few hours to many years, depending on pathogen characteristics and environmental factors (Traversa et al. 2014; Chenais et al. 2018). With regard to carcasses, it is assumed that, in general terms, the number of infective forms and their survival decreases as the distance to the carcass site increases and over time, although few studies have investigated this topic (Turnbull et al. 1998; Fialho et al. 2018; Rossi et al. 2019).

Among the non-trophically transmitted pathogens that cause the greatest impact on wildlife is the mite Sarcoptes scabiei, an obligate permanent parasite that causes sarcoptic mange (Niedringhaus et al. 2019). This multi-host ectoparasite is widely distributed and affects a broad range of mammals, including ungulates and carnivores (Carricondo-Sánchez et al. 2017; Pisano et al. 2019; Turchetto et al. 2020). These mites live in the epidermis of their hosts, and can be transmitted through direct contact between animals or indirectly when a susceptible host acquires free mites that have shed the skin of an infected animal, especially in dens and other sheltered sites where $S$. scabiei may survive for several days (Pence and Ueckermann 2002). Another infectious agent of major concern, due to its health impact on wildlife populations, is the bacterium Bacillus anthracis, which causes anthrax in ungulates and, to a lesser extent, in carnivores (Hugh-Jones and de Vos 2002). After the death of the infected animal, this virulent pathogen produces spores around the carcass that can persist in the environment for years, infecting new hosts via ingestion or inhalation (Bellan et al. 2013; Turner et al. 2014). Other widely distributed, nontrophically transmitted infectious agents that can seriously affect wild carnivore populations are rabies, distemper virus and canine parvovirus, which can be acquired through the saliva, respiratory secretions and feces of infected animals, respectively (Truyen et al. 1998; Nouvellet et al. 2013; McElhinney et al. 2014).

One of the paradigmatic hosts of these pathogens is the red fox (Vulpes vulpes), the most broadly distributed mammalian carnivore worldwide. This generalist species feeds upon a wide array of trophic resources, including vertebrate and invertebrate prey, plants, fungi and carrion (Wilson and Mittermeier 2009; Mateo-Tomás et al. 2015). Foxes occupy a wide range of habitats, including urban and peri-urban areas (Wilson and Mittermeier 2009). The ubiquity and ecological plasticity of foxes has led to recurrent scientific discussions about their epidemiological role in the maintenance and dispersion of pathogens with potential zoonotic and veterinary significance (Di Cerbo et al. 2008; Karamon et al. 2018).

Our main goal is to explore the behavior of potential hosts of non-trophically transmitted pathogens at carnivore carcass sites, with a special emphasis on the red fox. For this purpose, we monitored the decomposition process of fox and other mesocarnivore carcasses in several areas that differ in their communities of vertebrate carnivores and levels of anthropization. Analyzed behaviors include direct contact, marking and rubbing, either on the carcass or in its vicinities. Our main hypothesis is that the risk of acquiring pathogens through direct contact is dependent on both time since the carcass became available and carcass type (conspecific vs. heterospecific regarding the consumer), and that hosts rely on indirect cues to shape their behavior at carcass sites. Overall, we predict that risky behaviors will be more frequent at late stages of carcass decomposition and in heterospecific carcasses. This study may provide important insights to further understand the landscape of disgust associated with carrion, as well as the possible epidemiological consequences of this host behavior (Buck et al. 2018; Weinstein et al. 2018a; Doherty and Ruehle 2020; Moleón and Sánchez-Zapata 2021). This kind of study may be especially relevant in the current SARS-CoV-2 pandemic context, which has highlighted the need to investigate the forms of transmission of this emerging pathogen (Wong et al. 2020) in wild species, especially in mesocarnivores (Leroy et al. 2020; Tiwari et al. 2020).

\section{Material And Methods}

\section{Study areas}

Fieldwork was carried out in three mountainous areas of southeastern Spain: Sierras de Cazorla, Segura y Las Villas Natural Park (hereafter Cazorla; 2,099 km², 38 $09^{\prime} \mathrm{N} 2^{\circ} 44^{\prime} \mathrm{W}$ ), Sierra Espuña Regional Park (hereafter Espuña; $178 \mathrm{~km}^{2}, 37^{\circ} 51^{\prime} \mathrm{N} 1^{\circ} 32^{\prime} \mathrm{W}$ ) and periurban areas of Murcia city (hereafter Murcia; $415 \mathrm{~km}^{2}, 37^{\circ} 57^{\prime} \mathrm{N} 1^{\circ} 02^{\prime} \mathrm{W}$ ). Natural vegetation in these three areas is dominated by pine forests (mostly Pinus halepensis at low altitudes and P. nigra and P. pinaster at higher altitudes), aromatic shrubs, and patches of oak forests (Quercus ilex and Q. faginea) (Rivas-Martínez et al. 1987). There is an altitudinal and meteorological gradient from Cazorla (500-2,107 m a.s.l.; mean annual temperature: $12-16^{\circ} \mathrm{C}$; mean annual precipitation: $\left.300-950 \mathrm{~mm}\right)$ to Espuña $\left(200-1,583 \mathrm{~m}\right.$ a.s.l.; $\left.13-18^{\circ} \mathrm{C} ; 300-500 \mathrm{~mm}\right)$ and Murcia (190$490 \mathrm{~m}$ a.s.l.; $17-23^{\circ} \mathrm{C} ; 200-450 \mathrm{~mm}$ ) (www.juntadeandalucia.es; siam.imida.es). Meso-, Supra- and Oro-Mediterranean stages are represented in Cazorla, Thermo-, Meso- and Supra-Mediterranean stages in Espuña, and Thermo- and Meso-Mediterranean stages in Murcia. Cazorla and Espuña are protected areas, while Murcia supports moderate to high levels of anthropization, including scattered residential areas and herbaceous and fruit tree cultivations (mainly citrus trees).

In general, vertebrate communities are much richer in Cazorla, which holds a large resident population of obligate scavengers (i.e., vultures) and a wide variety of facultative scavengers. The scavenging community is similar in Espuña, though vultures are less abundant. In Murcia, 
vultures are mostly absent, and domestic carnivores, such as the dog (Canis lupus familiaris) and the cat (Felis silvestris catus), are more frequent. The fox is the commonest wild mammalian carnivore in the three study areas, though it is more abundant in Espuña than in Cazorla; there are no detailed data for Murcia. For more information on Cazorla and Espuña, see Moleón et al. (2017) and Morales-Reyes et al. (2017).

\section{Data collection}

A total of 66 mesocarnivore carcasses were monitored in Cazorla ( $n=27$ foxes), Murcia ( $n=19$ foxes) and Espuña ( $n=20$ carcasses, including ten foxes, four stone martens Martes foina, three Eurasian badgers Meles meles, two common genets Genetta genetta and one wildcat Felis silvestris silvestris) from November 2016 to March 2018. The main research model was the fox because it is the most abundant carnivore in the studied areas. Hereafter, carcasses of carnivores other than foxes are designated as "other carcasses". Carcasses came from authorized hunting (only in the case of foxes) and recent road kills (foxes and other carnivores). Immediately after collection, carcasses were eviscerated, and a serum sample was taken from each animal to perform enzyme-linked immunosorbent assays for antibody detection (ELISA kits, Ingenasa ${ }^{\circledR}$, Madrid, Spain) against some infectious diseases (canine distemper virus CDV, feline coronavirus FCoV, canine and feline parvovirus CPV/FPV, feline leukemia virus FeLV and feline immunodeficiency virus FIV). In addition, muscle samples from the base of the tongue, the forearms and diaphragm were processed by artificial digestion to detect the presence of Trichinella spp. larvae (Kapel et al. 1994; Gamble et al. 2000). Carcasses used in the study were free from these pathogens, and no lesions compatible with sarcoptic mange, mycosis or other pathologies were detected. In the case of hunted foxes, the tissues adjacent to the shot were removed to eliminate any trace of lead. After necropsy, carcasses were frozen at $-20^{\circ} \mathrm{C}$ in individual plastic bags, with the time elapsed between carnivore death and freezing being less than $18 \mathrm{~h}$ (Moleón et al. 2017).

Carcasses were defrosted before their placement in the field for $12-24 \mathrm{~h}$ at room temperature. Carcasses were randomly distributed throughout the study areas, with a minimum distance between neighboring cameras of at least $1 \mathrm{~km}$ (Moleón et al. 2017). Each carcass was fixed to a rock or a tree trunk with $1.5 \mathrm{~mm}$ diameter steel wires to avoid movement of the carcasses by scavengers away from the recording field of the camera. The wires were camouflaged with plants and soil (Moleón et al. 2015). Altitudinal range for carcass sites was 772-1676 m a.s.l. in Cazorla, 433-1432 m a.s.l. in Espuña and 125-448 m a.s.l. in Murcia. On the micro-habitat scale (i.e., radius of $10 \mathrm{~m}$ around the carcass), sampling places were categorized as "close areas", when the vertical projection of trees and shrubs exceeded $50 \%$, and "open areas" otherwise.

Carcasses were monitored using automatic cameras (Bushnell Trophy Cam and Bushnell Aggressor) until complete consumption (i.e., no remains, or only fur left) or for a maximum of 10 weeks if the carcass was not completely consumed (i.e., bones and skin remained). Cameras were placed in discreet locations close to the carcasses (3-4 $\mathrm{m}$ ) and were programmed to record a 15-second video every minute when detecting movement. Each carcass site was visited weekly to check batteries and memory cards. Cameras provided information on the presence of vertebrate species and their behavior at carcass sites. Recorded vertebrate species were classified into three groups: "red fox", "other mammals" and "birds" (the reptile Timon lepidus was also included in this last group, due to the scarce number of events in which this species was recorded). Based on O'Brien et al. (2003) and Ridout and Linkie (2009), we defined independent events for each carcass as: a) consecutive videos of unequivocally different individuals of the same species or individuals of different species; $b$ ) when individual identification was not possible, consecutive videos of individuals of the same species taken more than 30 minutes apart; and c) nonconsecutive videos of individuals of the same species. For each event, we recorded a) the species group, b) the number of different individuals, c) the existence of direct contact between the visitor and the carcass, $d$ ) the existence of marking behavior (urine and feces deposition), e) the existence of rubbing behavior, and f) the minimum distance between the visitor and the carcass ("contact": distance $=0 \mathrm{~cm}$; "close": distance > 0-50 cm; "moderate": distance > 50-200 cm; "far": distance> $200 \mathrm{~cm}$ ). These distance intervals were also used to classify marking and rubbing sites.

\section{Data analyses: weekly behavioral patterns of species visiting the carcasses}

We explored the general spatiotemporal patterns of mesocarnivore carcass use by the studied vertebrate communities. First, for each study area and carcass type (foxes and others), we calculated, on a weekly basis, the proportion of carcasses that were contacted (i.e., with at least one direct contact event), marked (i.e., with at least one marking behavior event), rubbed (i.e., with at least one rubbing behavior event on the carcass or on the ground next to it), and visited but not contacted (i.e., no contact events recorded), for all vertebrates together and separately for each vertebrate group. For each study area and carcass type, we also estimated the number of contact, marking, rubbing and no contact events per carcass. Second, we calculated the accumulated number of carcasses that were a) detected, b) contacted (i.e., at least one contact event), c) marked (i.e., at least one marking event), and d) rubbed (i.e., at least one rubbing event) each week by foxes.

\section{Data analyses: determinants of fox behavior}

We used generalized linear models (GLMs) to analyze the factors influencing "time of first contact" (only carcasses with at least one contact event by foxes were used; $n=54$ ). We conducted two separate analyses, using these two different datasets: 1 ) all fox carcasses in the three study areas; and 2) both fox and other carcasses in Espuña only. The first analysis is mainly aimed at exploring the general behavior of foxes 
at conspecific carcasses, while the second is aimed at determining if fox behavior is influenced by carcass type. Time of first contact was calculated as the time elapsed since carcass detection by foxes until the first contact event by foxes. The sample unit for these analyses was the carcass. The explanatory variables for the first analysis were study "area" (Cazorla, Espuña, Murcia), "habitat" (close, open), "year", "season" (winter: November-February; spring: March and April), "hour" of carcass placement (morning: from dawn to 12:00h; afternoon: from 12:00h to dusk), and carcass "detection time" by foxes (i.e., time elapsed since carcass placement and its detection by fox, expressed in days). The explanatory variables for the second analysis were "carcass type" (fox, other) and carcass "detection time" by foxes.

We then ran univariate models (Gaussian error distributions and identity functions) with all the possible explanatory variables for each case. Model selection was based on Akaike's Information Criterion, which allows the identification of the most parsimonious model (lowest AIC) and ranks the remaining models. For each model, the AIC value was corrected for small sample sizes (AICc). Then, delta AICc ( $\triangle \mathrm{AICC}$ ) was calculated as the difference in AICc between each model and the best model in the evaluated set, and models with $\triangle \mathrm{AICc}<2$ were considered to have similar support (Burnham and Anderson 2002). We calculated the deviance $\left(D^{2}\right)$ explained by each candidate model according to this formula: $D^{2}=$ (null deviance - residual deviance) / null deviance *100 (Burnham and Anderson 2002).

Finally, we used Chi-square analyses to compare the minimum distance between visiting foxes and the carcass a) among study areas (only fox carcasses) and b) carcass types (only in Espuña). All analyses were done with R Studio software v1.0.143 (R Core Team 2018).

\section{Results}

\section{Visiting species}

We recorded a total of 2,383 events (58.9\% in Cazorla, 23.9\% in Murcia, 7.9\% in Espuña at fox carcasses, $9.3 \%$ in Espuña at other carcasses) of 41 vertebrate species (19 birds, 21 mammals and one reptile) visiting the carcasses. The average richness of visiting species per carcass in Cazorla was approximately double that in Murcia and Espuña (Tables S1 and S2). Domestic species (mainly dogs, but also cats, goats and sheep) were rarely recorded (1.4\% of total events; Table S2). The fox was the most frequently recorded species in the three study areas (40.3\% of total events). Mean number of different individuals per event was $1.1 \pm 0.9$ (range: 1-29), and groups of visitors (i.e., more than one individual) were recorded at $8.0 \%$ of total events. Groups were more frequently recorded for carrion crow (Corvus corone), wild boar (Sus scrofa), mouflon (Ovis aries musimon) and Eurasian jay (Garrulus glandarius) in Cazorla. The fox was very rarely observed in groups (Table S2).

\section{General patterns of contact, marking and rubbing behaviors}

Contact events represented $40.6 \%$ of the total recorded events (Fig. 1, Table 1). Considering all study areas together, the fox was the species that most frequently contacted carcasses (45.0\% of total contact events; Fig. 1, Tables 1 and S2). Intraspecific contact was recorded at $100 \%$ of carcasses in Cazorla, 63.2\% in Murcia, and 60.0\% (fox carcasses) and 30.0\% (other carcasses) in Espuña. In foxes, intraspecific contact was detected in $43.4 \%$ of the total events recorded. In Espuña, events (especially contact events) of foxes and other mammals, but not of birds, were more frequently recorded at carcasses of other mesocarnivores (Fig. 1). Contact of both domestic and wild species with the same carcass took place at six carcasses in Cazorla (22.2\% of total carcasses in this area), three in Murcia (15.8\%) and two carcasses of other mesocarnivores in Espuña (20.0\% of total non-fox carcasses). Contact between individuals of different visiting species at carcass sites was recorded only once, between a golden eagle (Aquila chrysaetos) and a griffon vulture (Gyps fulvus) in Cazorla. 
Table 1

Carcass use patterns per study area and carcass type, according to different vertebrate species groups. Number of monitored carcasses is indicated for each study area and carcass type. The number of carcasses visited, contacted, marked and rubbed by each vertebrate group is shown together with the percentage relative to the total carcasses monitored per area and carcass type (in parentheses). Mean number of events per carcass \pm SD is shown for total, contact, marking and rubbing events. We considered carcasses contacted, marked and rubbed as those carcasses with at least one event with contact, marking or rubbing by a given vertebrate group. Similarly, we considered contact, marking and rubbing events as those events with at least one contact, marking or rubbing behavior recorded.

\begin{tabular}{|c|c|c|c|c|c|c|c|c|c|c|c|}
\hline Area & $\begin{array}{l}\text { Carcass } \\
\text { type }\end{array}$ & $\mathbf{N}$ & Group & $\begin{array}{l}\text { Carcasses } \\
\text { visited }\end{array}$ & $\begin{array}{l}\text { Carcasses } \\
\text { contacted }\end{array}$ & $\begin{array}{l}\text { Carcasses } \\
\text { marked }\end{array}$ & $\begin{array}{l}\text { Carcasses } \\
\text { rubbed }\end{array}$ & $\begin{array}{l}\text { Total } \\
\text { events }\end{array}$ & $\begin{array}{l}\text { Contact } \\
\text { events }\end{array}$ & $\begin{array}{l}\text { Marking } \\
\text { events }\end{array}$ & $\begin{array}{l}\text { Rubbing } \\
\text { events }\end{array}$ \\
\hline \multirow[t]{4}{*}{ Cazorla } & Foxes & 27 & Red fox & 27 (100\%) & 27 (100\%) & $\begin{array}{l}20 \\
(74.1 \%)\end{array}$ & $9(33.3 \%)$ & $\begin{array}{l}22.0 \pm \\
13.8\end{array}$ & $\begin{array}{l}10.2 \pm \\
9.0\end{array}$ & $\begin{array}{l}2.8 \pm \\
4.1\end{array}$ & $0.7 \pm 1.6$ \\
\hline & & & $\begin{array}{l}\text { Other } \\
\text { mammals }\end{array}$ & 27 (100\%) & $\begin{array}{l}23 \\
(85.2 \%)\end{array}$ & $9(33.3 \%)$ & $8(29.7 \%)$ & $\begin{array}{l}17.0 \pm \\
9.6\end{array}$ & $1 \pm 5.0$ & $\begin{array}{l}0.4 \pm \\
0.8\end{array}$ & $0.5 \pm 0.9$ \\
\hline & & & Birds & $\begin{array}{l}21 \\
(77.8 \%)\end{array}$ & $\begin{array}{l}18 \\
(66.7 \%)\end{array}$ & 0 (0\%) & 0 (0\%) & $\begin{array}{l}12.9 \pm \\
15.6\end{array}$ & $\begin{array}{l}7.4 \pm \\
10.3\end{array}$ & 0 & 0 \\
\hline & & & Total & 27 (100\%) & 27 (100\%) & $\begin{array}{l}22 \\
(81.5 \%)\end{array}$ & $\begin{array}{l}14 \\
(51.2 \%)\end{array}$ & $\begin{array}{l}51.9 \pm \\
25.6\end{array}$ & $\begin{array}{l}23.1 \pm \\
16.7\end{array}$ & $\begin{array}{l}3.3 \pm \\
4.6\end{array}$ & $1.2 \pm 1.9$ \\
\hline \multirow[t]{4}{*}{ Murcia } & Foxes & 19 & Red fox & $\begin{array}{l}16 \\
(84.2 \%)\end{array}$ & $\begin{array}{l}12 \\
(63.2 \%)\end{array}$ & 9 (47.4\%) & $4(14.8 \%)$ & $\begin{array}{l}8.4 \pm \\
8.8\end{array}$ & $\begin{array}{l}3.3 \pm \\
3.9\end{array}$ & $\begin{array}{l}1.2 \pm \\
1.6\end{array}$ & $0.6 \pm 1.3$ \\
\hline & & & $\begin{array}{l}\text { Other } \\
\text { mammals }\end{array}$ & $\begin{array}{l}16 \\
(84.2 \%)\end{array}$ & $9(47.4 \%)$ & $0(0 \%)$ & 0 (0\%) & $\begin{array}{l}6.9 \pm \\
10.6\end{array}$ & $\begin{array}{l}3.5 \pm \\
8.1\end{array}$ & 0 & 0 \\
\hline & & & Birds & $\begin{array}{l}15 \\
(78.9 \%)\end{array}$ & $9(47.4 \%)$ & $0(0 \%)$ & $0(0 \%)$ & $\begin{array}{l}14.6 \pm \\
17.3\end{array}$ & $\begin{array}{l}1.6 \pm \\
2.6\end{array}$ & 0 & 0 \\
\hline & & & Total & 19 (100\%) & $\begin{array}{l}16 \\
(84.2 \%)\end{array}$ & $9(47.4 \%)$ & $4(14.8 \%)$ & $\begin{array}{l}30.0 \pm \\
25.2\end{array}$ & $\begin{array}{l}8.4 \pm \\
9.0\end{array}$ & $\begin{array}{l}1.2 \pm \\
1.6\end{array}$ & $0.6 \pm 1.3$ \\
\hline \multirow[t]{8}{*}{ Espuña } & Foxes & 10 & Red fox & 9 (90.0\%) & $6(60.0 \%)$ & $4(40.0 \%)$ & 1 (10.0\%) & $\begin{array}{l}7.7 \pm \\
6.2\end{array}$ & $\begin{array}{l}2.4 \pm \\
3.5\end{array}$ & $\begin{array}{l}0.9 \pm \\
1.5\end{array}$ & $0.4 \pm 1.3$ \\
\hline & & & $\begin{array}{l}\text { Other } \\
\text { mammals }\end{array}$ & $10(100 \%)$ & $6(60.0 \%)$ & $2(20.0 \%)$ & $1(10.0 \%)$ & $\begin{array}{l}2.8 \pm \\
2.4\end{array}$ & $\begin{array}{l}0.7 \pm \\
0.7\end{array}$ & $\begin{array}{l}0.2 \pm \\
0.4\end{array}$ & $0.1 \pm 0.3$ \\
\hline & & & Birds & $8(80.0 \%)$ & $6(60.0 \%)$ & $0(0 \%)$ & $0(0 \%)$ & $\begin{array}{l}8.3 \pm \\
15.2\end{array}$ & $\begin{array}{l}4.3 \pm \\
6.7\end{array}$ & 0 & 0 \\
\hline & & & Total & 10 (100\%) & 10 (100\%) & $5(50.0 \%)$ & $2(20.0 \%)$ & $\begin{array}{l}18.8 \pm \\
18.4\end{array}$ & $\begin{array}{l}7.4 \pm \\
8.7\end{array}$ & $\begin{array}{l}1.1 \pm \\
1.6\end{array}$ & $0.5 \pm 1.3$ \\
\hline & Other & 10 & Red fox & 10 (100\%) & $9(90.0 \%)$ & $1(10.0 \%)$ & $2(20.0 \%)$ & $\begin{array}{l}12.9 \pm \\
24.1\end{array}$ & $\begin{array}{l}7.5 \pm \\
16.8\end{array}$ & $\begin{array}{l}0.6 \pm \\
1.9\end{array}$ & $0.5 \pm 1.1$ \\
\hline & & & $\begin{array}{l}\text { Other } \\
\text { mammals }\end{array}$ & $\begin{array}{l}10 \\
(10.0 \%)\end{array}$ & 8 (80.0\%) & $5(50.0 \%)$ & $2(20.0 \%)$ & $\begin{array}{l}5.1 \pm \\
4.3\end{array}$ & $\begin{array}{l}1.9 \pm \\
1.6\end{array}$ & $\begin{array}{l}0.9 \pm \\
1.3\end{array}$ & $0.2 \pm 0.4$ \\
\hline & & & Birds & $7(70.0 \%)$ & $5(50.0 \%)$ & $0(0 \%)$ & $0(0 \%)$ & $\begin{array}{l}4.2 \pm \\
4.9\end{array}$ & $\begin{array}{l}1.7 \pm \\
2.2\end{array}$ & 0 & 0 \\
\hline & & & Total & 10 (100\%) & 10 (100\%) & $6(60.0 \%)$ & 3 (30.0\%) & $\begin{array}{l}22.2 \pm \\
22.4\end{array}$ & $\begin{array}{l}11.1 \pm \\
16.1\end{array}$ & $\begin{array}{l}1.5 \pm \\
2.0\end{array}$ & $0.7 \pm 1.3$ \\
\hline
\end{tabular}

Marking and rubbing behaviors were recorded in $5.7 \%$ and $2.4 \%$ of total events, respectively (Table 1, Fig. 1). Most marking (62.8\%) and rubbing (82.5\%) events involved direct contact with the carcass. The fox was the most frequently recorded species marking (83.1\% of total marking events) and rubbing on the carcass or on the adjacent ground (70.1\% of total rubbing events). No marking or rubbing behaviors were observed for birds (Table 1, Fig. 1). Regarding total marking events, urination was more frequently recorded than defecation in foxes (85.2\% of total marking events) and other mammals (73.9\%).

\section{Weekly patterns in fox behavior}

Carcasses in all the study areas were detected by foxes from the first week. The number of red fox contact events peaked in the second to sixth week in the case of fox carcasses in all areas. In Espuña, the peak for other carcasses took place in the second week, i.e., two weeks earlier than the peak for fox carcasses in this area. While the first contacts with fox carcasses in Cazorla and Murcia, and with other carcasses in Espuña, were recorded in the first week after their deployment, the first events of contact with fox carcasses in Espuña were detected in the second week. In Espuña, foxes contacted more heterospecific carcasses than conspecific ones (Table 1, Fig. 1). 
The accumulated number of fox carcasses contacted by fox ranged between $100 \%$ in Cazorla to $60 \%$ in Espuña; in the latter area, foxes contacted $90 \%$ of carcasses of other carnivores (Fig. 2). While marking by foxes was anecdotal for other carcasses (10\%), foxes marked $40-$ $74 \%$ of fox carcasses (Fig. 2). At conspecific carcass sites, rubbing by foxes was less frequent than marking in all study areas, while the opposite was true for heterospecific carcass sites (Table 1, Fig. 2).

According to the GLMs, with regards to fox carcasses in the three study areas, the time elapsed between carcass detection and contact by foxes was mostly related to habitat (Table 2), with foxes contacting carcasses sooner in open habitats (Table 3). Regarding carcasses of fox and other carnivores in Espuña, the time of first contact by foxes was mainly dependent on carcass type (Table 2), with foxes contacting heterospecific earlier than conspecific carcasses (Table 3); hour of carcass placement and carcass detection time by foxes also had an influence (Tables 2 and 3). However, selected models explained little of the variability in the response variable, as revealed by their low $D^{2}$ values (<11\%; Table 2), which indicates that fox behavior was mostly conditioned by other variables not taken into account in this study.

Table 2

AlCc-based model selection to assess the factors influencing "time of first contact" by foxes of mesocarnivore carcasses in three study areas of southeastern Spain ("among areas" comparisons) and on conspecific and heterospecific carcasses in one of these study areas ("fox vs. other carcasses" comparisons). Explanatory variables include study "area", "habitat", "year", "season", "hour", and "carcass type"

(see main text for details on the variables). Number of estimated parameters $(\mathrm{k})$,

AICc values, AICc differences ( $\triangle \mathrm{AICC}$ ) with the model with the lowest AICc, and the variability of the models explained by the predictors (deviance, $D^{2}$ ) are shown. Selected models are in bold.

\begin{tabular}{|llllll|}
\hline Comparison & Model & k & AlCc & AAICc & D $^{2}$ \\
\hline Among areas (fox carcasses) & habitat & 1 & 342.58 & 0 & 7.89 \\
& detection time & 1 & 346.22 & 3.64 & \\
& season & 1 & 346.53 & 3.95 & \\
& hour & 1 & 346.57 & 3.99 & \\
\hline yox vs. other carcasses & year & 2 & 347.21 & 4.63 & \\
\hline & carcass & 1 & 113.35 & 0 & 10.79 \\
\hline & detection time & 1 & 114.21 & 0.86 & 5.50 \\
\hline & hour & 1 & 114.29 & 0.94 & 5.04 \\
\hline
\end{tabular}

Table 3

Generalized linear models (GLMs) showing the relationship between "time of first contact" by foxes with the explanatory variables included in the selected models ("habitat": open, close; "carcass" type: fox, other; "detection time": carcass detection time by foxes; "hour": morning, afternoon). Only selected models are shown, ordered from highest to lowest $D^{2}$. The estimate of the parameters (including the sign), the standard error of the parameters (SE) and the degree of freedom of the models (df) are shown.

\begin{tabular}{|llllll|}
\hline Comparison & Model & Parameter & Estimate & SE & df \\
\hline Among areas (fox carcasses) & habitat & Intercept & 11.40 & 1.89 & 44 \\
\hline Fox vs. other carcasses & carcass & habitat (open) & -6.67 & 3.27 & \\
\hline & & Intercept & 12.38 & 3.53 & 14 \\
\hline & detection time & Intercept & 11.21 & 3.48 & 14 \\
\hline & & detection time & -0.30 & 0.34 & \\
\hline & hour & Intercept & 9.69 & 2.48 & 14 \\
\hline
\end{tabular}

\section{Fox behavior in relation to distance to carcass}


Most of the recorded events involving foxes occurred close to the carcasses (Fig. 3). The average distance between foxes and conspecific carcasses was similar in the three study areas (Cazorla and Murcia: $\chi^{2}=1.603$, d.f. $=3, p=0.7$; Cazorla and Espuña: $\chi^{2}=4.792$, d.f. $=2$, $p=0.09$; Murcia and Espuña: $\chi^{2}=1.939$, d.f. $=2, p=0.4$ ). However, we observed differences between carcass types: within Espuña, we recorded more fox events close to heterospecific carcasses than to conspecific ones $\left(\chi^{2}=16.392\right.$, d.f. $=2, p<0.001$; Fig. 3).

\section{Discussion}

We carried out a detailed behavioral study of carnivore vertebrates, including scavenging and non-scavenging species, at mammalian carnivore carcass sites, which may represent hotspots for non-trophically transmitted pathogens. To date, few studies have addressed how perceived risk of acquiring pathogens shapes the landscape of disgust of animals (Buck et al. 2018; Weinstein et al. 2018a), and none of these studies have focused on non-trophically transmitted pathogens related to carnivore carcasses (Moleón and Sánchez-Zapata 2021). Thus, patterns arising from our study may provide a basis for a more accurate interpretation of the ecological aspects that characterize nontrophically transmitted pathogens in the wild (Polley and Thompson 2015), which is especially relevant in a global context of zoonotic diseases (Evans et al. 2020; Leroy et al. 2020; Tiwari et al. 2020).

\section{Visitor behavior at carnivore carcass sites}

Carnivore carcass sites were visited by a rich community of vertebrates, though their behavior differed widely among species groups, study areas and carcass types. The long persistence of mesocarnivore carcasses in the environment due to their relatively low consumption rate (Moleón et al. 2017; Muñoz-Lozano et al. 2019) probably favored the visiting of numerous species during the long decomposition period, which lasted up to ten weeks. Contact between the visitor and the carcass was frequently recorded. However, direct contact between two different visitor species was hardly ever recorded, and it was never observed between mammals. This contrasts with herbivore carcasses, in which mammalian scavengers may have more opportunities for contact (Borchering et al. 2017), especially in the absence of competition with vultures (Ogada et al. 2012). In carnivore carcasses, visits of mammals are more spaced than in herbivore carcasses, where many scavengers can gather in the short interval during which meat is available. Thus, at carnivore carcass sites, infection risk may take place mainly for visitorcarcass contact rather than direct contact between visitors.

Visitor behavior at carcass sites was highly dependent on the scavenging habits of the species. In our study, scavenging species were responsible for most contact events (53.1-96.5\%, depending on the study area; see Table S2). Contacts by non-scavengers were mainly by small passerine birds that were observed taking hair from carcasses for nest construction (Moleón and Sánchez-Zapata 2016; Moleón et al. 2017; authors' pers. observ.; note that these species can also scavenge occasionally and prey on necrophagous insects; Moreno-Opo and Margalida 2013). Herbivores avoid carcass sites because they pose a higher risk of being attacked by scavenging predators (Cortés-Avizanda et al. 2009; Moleón and Sánchez-Zapata 2021), so carnivore carcasses should represent a low infection risk for these species in the shortterm. In the mid- and long-term, however, the vegetation that vigorously grows around carcass sites (Barton et al. 2013) may attract herbivores and, consequently, may increase the risk of infection by certain soil-borne pathogens with persistent infective stages in the environment (Johnson and Thieltges 2010; Turner et al. 2014), such as eggs of Taenia spp., a cestode genus that includes several species of parasites whose intermediate and definitive hosts are ungulates and mammalian carnivores, respectively (Lesniak et al. 2017). Nevertheless, vegetation responses are probably weak for relatively small carcasses such as those of mesocarnivores (Teurlings et al. 2020).

Marking and rubbing behaviors were only observed for mammal visitors. Scent-marking is very frequent in carnivores and many other mammals for interspecific and, mostly, intraspecific communication. Odors derived from marking with urine, saliva or feces are not only important for territory delimitation and defense (Ralls 1971; Johnson 1973; Sillero-Zubiri and Macdonald 1998), but also play a prominent role in assessing the health status of conspecifics in many mammalian species (Poirotte et al. 2017; Kavaliers and Choleris 2018; Kavaliers et al. 2020). The frequent marking behavior observed also suggests that carnivore carcass sites may concentrate more persistent infective stages excreted by urine or feces from the host than in the surrounding landscape. This is the case, for example, for canine parvovirus (Miranda et al. 2017), canine distemper virus (Beineke et al. 2015), Leptospira spp. (Millán et al. 2019) and ascarids (Okulewicz et al. 2012). Marking events may also increase the attractant effect of carcass sites for both conspecifics and heterospecifics, favoring a positive feedback loop that could promote inter- and intraspecific transmission of pathogens at carcass sites (Banks et al. 2016). All of this evidence indicates the need for further research on the effect that marking a carcass site may have, not only on animal behavior, but also on the transmission and maintenance of pathogens in the wild.

Rubbing, or scent-rubbing, is also very frequent in mammals such as carnivores, though the eco-evolutionary significance of this behavior is far from clear (Rieger 1979; Gosling and McKay 1990). In our study, direct contact with the carcass was much more frequent in rubbing events than in marking ones, which suggests that the risk of acquiring multi-host pathogens transmitted directly through non-trophic mechanisms, such as S. scabiei (Arlian et al. 1989; Kołodziej-Sobocińska et al. 2014) or ticks (Hofmeester et al. 2018), is higher for wild canids, mustelids 
and viverrids that display rubbing behavior. In addition to ectoparasites, as the carcass decays, diverse endoparasite infective stages can spread around the carcass, such as Toxocara canis eggs, an intestinal nematode transmitted by fecal-oral route that affects domestic and wild canids (Roddie et al. 2008). Thus, touching, rubbing against the carcass or sniffing it can also be a route of contagion for this and other directly transmitted endoparasites.

Domestic species, represented by livestock (goats and sheep) and pets (dogs and cats), were recorded in a very low proportion of total and contact events, even for the most anthropized area (Murcia). This suggests that carnivore carcasses are not important hotspots of pathogen transmission for these species, at least in our study areas. There is general concern for rabies circulation among dogs, other domestic animals, wildlife and humans in several parts of the world (Hughes and Macdonald 2013; Nadin-Davis et al. 2021), though there are no cases of rabies in our study areas. However, these interactions must be considered to study other pathogens with high epidemiological relevance at the wildlife-domestic-human interface, such as SARS-CoV-2, which is characterized by rapid spread and interspecies-jumping capacity (Leroy et al. 2020). Further studies should be promoted in regions where potential contact between wildlife and domestic animals is higher.

\section{Fox behavior in relation to carcass type}

We found important behavioral differences of red foxes at conspecific and heterospecific carcasses in Espuña. Foxes contacted heterospecific carcasses more frequently and earlier than conspecific ones, as confirmed by the GLMs, and close contact was more frequently observed at heterospecific carcasses than at fox carcasses. Similarly, rubbing by foxes was more frequent at heterospecific than conspecific carcass sites in Espuña. All of this is in accordance with the hypotheses that, in general, infection risk is higher for phylogenetically related species (Huang et al. 2014), and that carnivores avoid feeding upon conspecific carcasses because the risk of acquiring species-specific meat-borne pathogens is at a maximum (Hart 2011; Moleón et al. 2017). In the case of sarcoptic mange, the observed fox's greater reluctance to contact conspecific carrion is consistent with the fact that canids have a higher susceptibility to sarcoptic mange than other mesocarnivore species (Astorga et al. 2018; Niedringhaus et al. 2019). It should be noted that carcasses used in our study belonged to healthy animals that presented a good body condition and no skin lesions compatible with sarcoptic mange. However, in the initial stages of the disease, mangy animals do not present evident lesions, which suggests that even carrion that does not have sarcoptic lesions may be infectious to the host that contacts it.

The behavior of contacting carcasses peaked several weeks after carcass deployment, especially for conspecific carcasses. Off-host survival of ectoparasites such as mites and lice decrease with time after the host dies, with survival being affected by environmental temperature and humidity (Arlian et al. 1984, 1989; Pérez-Jiménez et al. 1990). In our Mediterranean study areas, characterized by mild and dry environmental conditions, off-host survival of ectoparasites and other pathogens is probably lower than in colder and more humid environments. Foxes visiting carcasses seemed to avoid contacting them during the period of maximum risk of acquiring ectoparasites, i.e., the first weeks after the carcass was available. However, other infective stages such as ascarid eggs, some viruses or spore-forming bacteria may survive for longer periods in the carcass vicinities (Turner et al. 2014; Beineke et al. 2015; Holland 2017; Miranda et al. 2017). In this case, the strategy of foxes to delay the propensity to contact carcasses would be ineffective to avoid infection risk. Moreover, the time elapsed in detecting carcasses was usually less than a week. From an epidemiological point of view, this indicates that, even if there is no direct contact with the carcass, there is still a risk of acquiring ectoparasites, especially in the case of those with greater mobility and capacity to leave the carcass, such as fleas and ticks (Domínguez 2004; Perrucci et al. 2016). These ectoparasites are detached from the body within a few hours after host death (Nelder and Reeves 2005), remaining around the carcass while waiting for a new host. Therefore, mesocarnivore carcass sites could be considered as an epidemiological factor influencing the transmission of vector-borne pathogens, especially those with zoonotic implications (Marié et al. 2012; Millán et al. 2016; Hofmeester et al. 2018).

Fox marking behavior was also conditioned by carcass type, as urination and defecation were more frequent for conspecific carcasses. This behavior does not entail, a priori, a direct contact with the carcass, so the risk of acquiring some pathogens that are usually transmitted by direct contact and have reduced mobility outside the host, such as lice and especially S. scabiei, is greatly reduced (Millán et al. 2016). This also suggests that marking behavior of the red fox is weakly inhibited by the infection risk associated with the presence of carcasses. In mammalian carnivores, marking is mainly associated with intraspecific communication (e.g. Sillero-Zubiri and Macdonald 1998). However, why foxes marked more conspecific than heterospecific carcasses is unclear. A possible explanation could be that fox carcasses are more attractive as long-term marking points than carcasses of other mesocarnivores. This is because the persistence of fox carcasses in the environment is higher than that of other mesocarnivore carcasses, as foxes are more prone to feed upon heterospecific carrion (Moleón et al. 2017; Muñoz-Lozano et al. 2019).

\section{Conclusions}

Here we disentangled the behavior of animals visiting mesocarnivore carcass sites, which may have important implications not only for understanding the epidemiology of non-trophically transmitted parasites, but also in eco-evolutionary terms. Contact events between 
scavengers and carcasses were far more frequent than consumption events (Moleón et al. 2017; Muñoz-Lozano et al. 2019; Gonzálvez 2020), suggesting that scavenger behavior is more constrained by the transmission risk of meat-borne parasites than the risk of acquiring nontrophically transmitted parasites. Overall, this study contributes to filling major gaps in the empirical knowledge of the role of carrion in the landscape of disgust (Moleón and Sánchez-Zapata 2021), and shows the promising and varied opportunities of studying animal behavior associated with carrion resources. The impact that emerging and re-emerging diseases associated with wildlife are having on modern societies makes it necessary to conduct these types of studies, providing key scientific evidence to improve our understanding of the epidemiological factors that occur in the wild.

\section{Declarations}

\section{Funding}

MM was supported by a research contract Ramón y Cajal from the MINECO (RYC-2015-19231). This study was funded by the Spanish Ministry of Economy, Industry and Competitiveness and EU ERDF funds through the project CGL2017-89905-R.

\section{Conflicts of interest}

None.

\section{Availability of data and material}

The datasets generated during and/or analysed during the current study are available from the corresponding author on reasonable request.

\section{Code availability}

Not applicable.

\section{Authors' contributions}

All authors contributed to the study conception and design. Material preparation, data collection and analysis were performed by MG, CMC and MM. The first draft of the manuscript was written by MG. CMC and MM revised the manuscript, and all authors commented on previous versions of the manuscript. All authors read and approved the final manuscript.

\section{Ethics approval}

Not applicable.

\section{Consent to participate}

Authors have permission to participate.

\section{Consent for publication}

Authors have permission for publication.

\section{References}

1. Acevedo MA, Dillemuth FP, Flick AJ, Faldyn MJ, Elderd BD (2019) Virulence-driven trade-offs in disease transmission: A meta-analysis. Evolution 73:636-647. https://doi.org/10.1111/evo.13724

2. Alizon S, Michalakis Y (2015) Adaptive virulence evolution: the good old fitness-based approach. Trends Ecol Evol 30:248-254. https://doi.org/10.1016/j.tree.2015.02.009

3. Altizer S, Nunn CL, Thrall PH, Gittleman JL, Antonovics J, Cunningham AA, Dobson AP, Ezenwa V, Jones KE, Pedersen AB, Poss M, Pullian JRC (2003) Social organization and parasite risk in mammals: integrating theory and empirical studies. Annu Rev Ecol Evol Syst 34:517547. https://doi.org/10.1146/annurev.ecolsys.34.030102.151725

4. Arlian LG, Runyan RA, Achar S, Estes SA (1984) Survival and infectivity of Sarcoptes scabiei var. canis and var. hominis. J Am Acad Dermatol 11:210-215. https://doi.org/10.1016/s0190-9622(84)70151-4

5. Arlian LG, Vyszenski-Moher DL, Pole MJ (1989) Survival of adults and development stages of Sarcoptes scabiei var. canis when off the host. Exp Appl Acarol 6:181-187. https://doi.org/10.1007/BF01193978 
6. Astorga F, Carver S, Almberg ES, Sousa GR, Wingfield K, Niedringhaus KD, Van Wick P, Rossi L, Xie Y, Cross P, Angelone S, Gortázar C, Escobar LE (2018) International meeting on sarcoptic mange in wildlife, June 2018, Blacksburg, Virginia. USA Parasit Vectors 11:449. https://doi.org/10.1186/s13071-018-3015-1

7. Banks PB, Daly A, Bytheway JP (2016) Predator odours attract other predators, creating an olfactory web of information. Biol Lett 12:20151053. https://doi.org/10.1098/rsbl.2015.1053

8. Barton PS, Cunningham SA, Lindenmayer DB, Manning AD (2013) The role of carrion in maintaining biodiversity and ecological processes in terrestrial ecosystems. Oecologia 171:761-772. https://doi.org/10.1007/s00442-012-2460-3

9. Beasley JC, Olson ZH, DeVault TL (2012) Carrion cycling in food webs: comparisons among terrestrial and marine ecosystems. Oikos 121:1021-1026. https://doi.org/10.1111/j.1600-0706.2012.20353.x

10. Beineke A, Baumgärtner W, Wohlsein P (2015) Cross-species transmission of canine distemper virus-an update. One Health 1:49-59. https://doi.org/10.1016/j.onehlt.2015.09.002

11. Bellan SE, Turnbull PCB, Beyer W, Getz WM (2013) Effects of experimental exclusion of scavengers from carcasses of anthrax-infected herbivores on Bacillus anthracis sporulation, survival, and distribution. Appl Environ Microbiol 79:3756-3761. https://doi.org/10.1128/AEM.00181-13

12. Borchering RK, Bellan SE, Flynn JM, Pulliam J, McKinley SA (2017) Resource-driven encounters among consumers and implications for the spread of infectious disease. J R Soc Interface 14:20170555. https://doi.org/10.1098/rsif.2017.0555

13. Bousema T, Griffin JT, Sauerwein RW, Smith DL, Churcher TS, Takken W, Ghani A, Drakeley C, Gosling R (2012) Hitting hotspots: spatial targeting of malaria for control and elimination. PLoS Med 9:e1001165. https://doi.org/10.1371/journal.pmed.1001165

14. Brouwer AF, Eisenberg MC, Love NG, Eisenberg J (2019) Phenotypic variations in persistence and infectivity between and within environmentally transmitted pathogen populations impact population-level epidemic dynamics. BMC Infect Dis 19:449. https://doi.org/10.1186/s12879-019-4054-8

15. Buck JC, Weinstein SB, Young HS (2018) Ecological and evolutionary consequences of parasite avoidance. Trends Ecol Evol 33:619-632. https://doi.org/10.1016/j.tree.2018.05.001

16. Burnham KP, Anderson DR (2002) Model selection and multimodel inference. A practical information-theoretic approach. Springer, New York. https://doi.org/10.1007/b97636

17. Byrom AE, Caley P, Paterson BM, Nugent G (2015) Feral ferrets (Mustela furo) as hosts and sentinels of tuberculosis in New Zealand. N Z Vet J 63:42-53. https://doi.org/10.1080/00480169.2014.981314

18. Carricondo-Sánchez D, Odden M, Linnell JDC, Odden J (2017) The range of the mange: spatiotemporal patterns of sarcoptic mange in red foxes (Vulpes vulpes) as revealed by camera trapping. PLoS One 12:e0176200. https://doi.org/10.1371/journal.pone.0176200

19. Chenais E, Ståhl K, Guberti V, Depner K (2018) Identification of wild boar-habitat epidemiologic cycle in African Swine Fever epizootic. Emerg Infect Dis 24:810-812. https://doi.org/10.3201/eid2404.172127

20. Cortés-Avizanda A, Selva N, Carrete M, Donázar JA (2009) Effects of carrion resources on herbivore spatial distribution are mediated by facultative scavengers. Basic Appl Ecol 10:265-272. https://doi.org/10.1016/j.baae.2008.03.009

21. DeVault TL, Rhodes OE, Shivik JA (2003) Scavenging by vertebrates: behavioural, ecological, and evolutionary perspectives on an important energy transfer pathway in terrestrial ecosystems. Oikos 102:225-234. https://doi.org/10.1034/j.1600-0706.2003.12378.x

22. Di Cerbo AR, Manfredi MT, Trevisiol K, Bregoli M, Ferrari N, Pirinesi F, Bazzoli S (2008) Intestinal helminth communities of the red fox (Vulpes vulpes L.) in the Italian Alps. Acta Parasitol 53:302-311. https://doi.org/10.2478/s11686-008-0042-7

23. Dmitric M, Vidanovic D, Vaskovic N, Matovic K, Sekler M, Debeljak Z, Karabasil N (2017) Trichinella infections in red foxes (Vulpes Vulpes) and golden jackals (Canis aureus) in six districts of Servia. J Zoo Wildl Med 48:703-707. https://doi.org/10.1638/2016-0169.1

24. Doherty JF, Ruehle B (2020) An integrated landscape of fear and disgust: the evolution of avoidance behaviors amidst a myriad of natural enemies. Front Ecol Evol 8:564343. https://doi.org/10.3389/fevo.2020.564343

25. Domínguez G (2004) North Spain (Burgos) wild mammals ectoparasites. Parasite 11:267-272. https://doi.org/10.1051/parasite/2004113267

26. Donázar JA (1993) Los buitres ibéricos. Biología y conservación. J. M. Reyero Editor, Madrid

27. Evans TS, Shi Z, Boots M, Liu W, Olival KJ, Xiao X, Vandewoude S, Brown H, Chen JL, Civitello DJ, Escobar L, Grohn Y, Li H, Lips K, Liu Q, Lu J, Martínez-López B, Shi J, Shi X, Xu B, Yuan L, Zhu G, Getz WM (2020) Synergistic China-US ecological research is essential for global emerging infectious disease preparedness. EcoHealth 17:160-173. https://doi.org/10.1007/s10393-020-01471-2

28. Ezenwa VO, Archie EA, Craft ME, Hawley DM, Martin LB, Moore J, White L (2016) Host behaviour-parasite feedback: an essential link between animal behaviour and disease ecology. Proc R Soc Lond [Biol] 283:20153078. https://doi.org/10.1098/rspb.2015.3078 
29. Fialho VS, Rodrigues VB, Elliot SL (2018) Nesting strategies and disease risk in necrophagous beetles. Ecol Evol 8:3296-3310. https://doi.org/10.1002/ece3.3919

30. Gamble HR, Bessonov AS, Cuperlovic K, Gajadhar AA, van Knapen F, Noeckler K, Schenone H, Zhu X (2000) International Commission on Trichinellosis: recommendations on methods for the control of Trichinella in domestic and wild animals intended for human consumption. Vet Parasitol 93:393-408. https://doi.org/10.1016/s0304-4017(00)00354-x

31. Gonzálvez M (2020) The role of wild carnivore carcasses in the transmission of infectious agents: epidemiological and ecological aspects. PhD thesis. University of Murcia, Murcia

32. Gosling LM, McKay HV (1990) Competitor assessment by scent matching: an experimental test. Behav Ecol Sociobiol 26:415-420. https://doi.org/10.1007/BF00170899

33. Hart BL (1990) Behavioral adaptations to pathogens and parasites: five strategies. Neurosci Biobehav Rev 14:273-294. https://doi.org/10.1016/s0149-7634(05)80038-7

34. Hart BL (2011) Behavioral defenses in animals against pathogens and parasites: parallels with the pillars of medicine in humans. Philos Trans R Soc B 366:3406-3417. https://doi.org/10.1098/rstb.2011.0092

35. Hofmeester TR, Krawczyk Al, Van Leeuwen AD, Fonville M, Montizaan M, Van den Berge K, Gouwy J, Ruyts SC, Verheyen K, Sprong H (2018) Role of mustelids in the life-cycle of ixodid ticks and transmission cycles of four tick-borne pathogens. Parasit Vectors 11:600. https://doi.org/10.1186/s13071-018-3126-8

36. Holland CV (2017) Knowledge gaps in the epidemiology of Toxocara: the enigma remains. Parasitology 144:81-94. https://doi.org/10.1017/S0031182015001407

37. Huang S, Bininda-Emonds OR, Stephens PR, Gittleman JL, Altizer S (2014) Phylogenetically related and ecologically similar carnivores harbour similar parasite assemblages. J Anim Ecol 83:671-680. https://doi.org/10.1111/1365-2656.12160

38. Hughes J, Macdonald DW (2013) A review of the interactions between free-roaming domestic dogs and wildlife. Biol Conserv 157:341351. https://doi.org/10.1016/j.biocon.2012.07.005

39. Hugh-Jones ME, de Vos V (2002) Anthrax and wildlife. Rev Sci Tech 21:359-383. https://doi.org/10.20506/rst.21.2.1336

40. Johnson RP (1973) Scent marking in mammals. Anim Behav 21:521-535. https://doi.org/10.1016/S0003-3472(73)80012-0

41. Johnson PTJ, Thieltges DW (2010) Diversity, decoys and the dilution effect: how ecological communities affect disease risk. J Exp Biol 213:961-970. https://doi.org/10.1242/jeb.037721

42. Kapel CM, Henriksen SA, Dietz HH, Henriksen P, Nansen P (1994) A study on the predilection sites of Trichinella spiralis muscle larvae in experimentally infected foxes (Alopex lagopus, Vulpes vulpes). Acta Vet Scand 35:125-132. https://doi.org/10.1186/BF03548339

43. Karamon J, Dąbrowska J, Kochanowski M, Samorek-Pieróg M, Sroka J, Różycki M, Bilska-Zając E, Zdybel J, Cencek T (2018) Prevalence of intestinal helminths of red foxes (Vulpes vulpes) in central Europe (Poland): a significant zoonotic threat. Parasit Vectors 11:436. https://doi.org/10.1186/s13071-018-3021-3

44. Kavaliers M, Choleris E (2018) The role of social cognition in parasite and pathogen avoidance. Philos Trans R Soc B 373:20170206. https://doi.org/10.1098/rstb.2017.0206

45. Kavaliers M, Ossenkopp KP, Choleris E (2020) Pathogens, odors, and disgust in rodents. Neurosci Biobehav Rev 119:281-293. https://doi.org/10.1016/j.neubiorev.2020.09.037

46. Kołodziej-Sobocińska M, Zalewski A, Kowalczyk R (2014) Sarcoptic mange vulnerability in carnivores of the Białowieża Primeval Forest, Poland: underlying determinant factors. Ecol Res 29:237-244. https://doi.org/10.1007/s11284-013-1118-x

47. Kuris AM (2003) Evolutionary ecology of trophically transmitted parasites. J Parasitol 89:S96-S100

48. Leroy EM, Ar Gouilh M, Brugère-Picoux J (2020) The risk of SARS-CoV-2 transmission to pets and other wild and domestic animals strongly mandates a one-health strategy to control the COVID-19 pandemic. One Health 10:100133. https://doi.org/10.1016/j.onehlt.2020.100133

49. Lesniak I, Heckmann I, Heitlinger E, Szentiks CA, Nowak C, Harms V, Jarausch A, Reinhardt I, Kluth G, Hofer H, Krone O (2017) Population expansion and individual age affect endoparasite richness and diversity in a recolonising large carnivore population. Sci Rep 7:41730. https://doi.org/10.1038/srep41730

50. Marié JL, Davoust B, Socolovschi C, Mediannikov O, Roqueplo C, Beaucournu JC, Raoult D, Parola P (2012) Rickettsiae in arthropods collected from red foxes (Vulpes vulpes) in France. Comp Immunol Microbiol Infect Dis 35:59-62. https://doi.org/10.1016/j.cimid.2011.10.001

51. Mateo-Tomás P, Olea PP, Moleón M, Vicente J, Botella F, Selva N, Viñuela J, Sánchez-Zapata JA (2015) From regional to global patterns in vertebrate scavenger communities subsidized by big game hunting. Divers Distrib 21:913-924. https://doi.org/10.1111/ddi.12330 
52. McElhinney LM, Marston DA, Brookes SM, Fooks AR (2014) Effects of carcase decomposition on rabies virus infectivity and detection. J Virol Methods 207:110-113. https://doi.org/10.1016/j.jviromet.2014.06.024

53. Millán J, Proboste T, De Mera IGF, Chirife AD, De la Fuente J, Altet L (2016) Molecular detection of vector-borne pathogens in wild and domestic carnivores and their ticks at the human-wildlife interface. Ticks Tick Borne Dis 7:284-290. https://doi.org/10.1016/j.ttbdis.2015.11.003

54. Millán J, Velarde R, Chirife AD, León-Vizcaíno L (2019) Carriage of pathogenic Leptospira in carnivores at the wild/domestic interface. Pol J Vet Sci 22:589-598. https://doi.org/10.24425/pjvs.2019.131408

55. Miranda C, Santos N, Parrish C, Thompson G (2017) Genetic characterization of canine parvovirus in sympatric free-ranging wild carnivores in Portugal. J Wildl Dis 53:824-831. https://doi.org/10.7589/2016-08-194

56. Moleón M, Martínez-Carrasco C, Muellerklein OC, Getz WM, Muñoz-Lozano C, Sánchez-Zapata JA (2017) Carnivore carcasses are avoided by carnivores. Anim Ecol 86:1179-1191. https://doi.org/10.1111/1365-2656.12714

57. Moleón M, Sánchez-Zapata JA (2016) Non-trophic functions of carcasses: from death to the nest. Front Ecol Environ 14:340-341. https://doi.org/10.1002/fee.1306

58. Moleón M, Sánchez-Zapata JA (2021) The role of carrion in the landscapes of fear and disgust: A review and prospects. Diversity 13:28. https://doi.org/10.3390/d13010028

59. Moleón M, Sánchez-Zapata JA, Sebastián-González E, Owen-Smith N (2015) Carcass size shapes the structure and functioning of an African scavenging assemblage. Oikos 124:1391-1403. https://doi.org/10.1111/oik.02222

60. Moleón M, Selva N, Sánchez-Zapata JA (2020) The components and spatiotemporal dimension of carrion biomass quantification. Trends Ecol Evol 35:91-92. https://doi.org/10.1016/j.tree.2019.10.005

61. Morales-Reyes Z, Sánchez-Zapata JA, Sebastián-González E, Botella F, Carrete M, Moleón M (2017) Scavenging efficiency and red fox abundance in Mediterranean mountains with and without vultures. Acta Oecol 79:81-88. https://doi.org/10.1016/j.actao.2016.12.012

62. Moreno-Opo R, Margalida A (2013) Carcasses provide resources not exclusively to scavengers: patterns of carrion exploitation by passerine birds. Ecosphere 4:105. https://doi.org/10.1890/ES13-00108.1

63. Muñoz-Lozano C, Martín-Vega D, Martínez-Carrasco C, Sánchez-Zapata JA, Morales-Reyes Z, Gonzálvez M, Moleón M (2019) Avoidance of carnivore carcasses by vertebrate scavengers enables colonization by a diverse community of carrion insects. PLoS One 14 :e0221890. https://doi.org/10.1371/journal.pone.0221890

64. Nadin-Davis SA, Falardeau E, Flynn A, Whitney H, Marshall HD (2021) Relationships between fox populations and rabies virus spread in northern Canada. PLoS One 16:e0246508. https://doi.org/10.1371/journal.pone.0246508

65. Nelder MP, Reeves WK (2005) Ectoparasites of road-killed vertebrates in northwestern South Carolina, USA. Vet Parasitol 129:313-322. https://doi.org/10.1016/j.vetpar.2004.02.029

66. Niedringhaus KD, Brown JD, Sweeley KM, Yabsley MJ (2019) A review of sarcoptic mange in North American wildlife. Int J Parasitol Parasites Wildl 9:285-297. https://doi.org/10.1016/j.ijppaw.2019.06.003

67. Nouvellet P, Donnelly CA, Nardi MD, Rhodes CJ, Benedictis PD, Citterio C, Obber F, Lorenzetto M, Pozza MD, Cauchemez S, Cattoli G (2013) Rabies and canine distemper virus epidemics in the red fox population of Northern Italy (2006-2010). PLoS One 8:e61588. https://doi.org/10.1371/journal.pone.0061588

68. O'Brien TG, Kinnaird MF, Wibisono HT (2003) Crouching tigers, hidden prey: Sumatran tiger and prey populations in a tropical forest landscape. Anim Conserv 6:131-139. https://doi.org/10.1017/S1367943003003172

69. Ogada DL, Torchin ME, Kinnaird MF, Ezenwa VO (2012) Effects of vulture declines on facultative scavengers and potential implications for mammalian disease transmission. Conserv Biol 26:453-460. https://doi.org/10.1111/j.1523-1739.2012.01827.x

70. Okulewicz A, Perec-Matysiak A, Buńkowska K, Hildebrand J (2012) Toxocara canis, Toxocara cati and Toxascaris leonina in wild and domestic carnivores. Helminthologia 49:3-10. https://doi.org/10.2478/s11687-012-0001-6

71. Olson ZH, Beasley JC, Rhodes OE (2016) Carcass type affects local scavenger guilds more than habitat connectivity. PLoS One 11:e0147798. https://doi.org/10.1371/journal.pone.0147798

72. Patterson J, Ruckstuhl K (2013) Parasite infection and host group size: a meta-analytical review. Parasitology 140:803-813. https://doi.org/10.1017/S0031182012002259

73. Pence DB, Ueckerman E (2002) Sarcoptic mange in wildlife. Rev Sci Tech 21:385-398. https://doi.org/10.20506/rst.21.2.1335

74. Penczykowski RM, Laine AL, Koskella B (2015) Understanding the ecology and evolution of host-parasite interactions across scales. Evol Appl 9:37-52. https://doi.org/10.1111/eva.12294

75. Pérez-Jiménez JM, Soler-Cruz MD, Benítez-Rodríguez R, Ruiz-Martínez I, Díaz-López M, Palomares-Fernández F, Delibes-de Castro M (1990) Phthiraptera from some wild carnivores in Spain. Syst Parasitol 15:107-117. https://doi.org/10.1007/BF00009987

Page 13/17 
76. Perrucci S, Verin R, Mancianti F, Poli A (2016) Sarcoptic mange and other ectoparasitic infections in a red fox (Vulpes vulpes) population from central Italy. Parasite Epidemiol Control 1:66-71. https://doi.org/10.1016/j.parepi.2016.03.007

77. Pisano S, Zimmermann F, Rossi L, Capt S, Akdesir E, Bürki R, Kunz F, Origgi FC, Ryser-Degiorgis MP (2019) Spatiotemporal spread of sarcoptic mange in the red fox (Vulpes vulpes) in Switzerland over more than 60 years: lessons learnt from comparative analysis of multiple surveillance tools. Parasit Vectors 12:521. https://doi.org/10.1186/s13071-019-3762-7

78. Poirotte C, Massol F, Herbert A, Willaume E, Bomo PM, Kappeler PM, Charpentier MJ (2017) Mandrills use olfaction to socially avoid parasitized conspecifics. Sci Adv 3:e1601721. https://doi.org/10.1126/sciadv.1601721

79. Polley L, Thompson A (2015) Parasites and wildlife in a changing world. Trends Parasitol 31:123-124. https://doi.org/10.1016/j.pt.2015.03.001

80. Poulin R (2007) Are there general laws in parasite ecology? Parasitology 134:763-776. https://doi.org/10.1017/S0031182006002150

81. R Core Team (2018) R: A language and environment for statistical computing. R Foundation for Statistical Computing. Vienna, Austria

82. Ralls K (1971) Mammalian scent marking. Science 171:443-449. https://doi.org/10.1126/science.171.3970.443

83. Ridout MS, Linkie M (2009) Estimating overlap of daily activity patterns from camera trap data. J Agric Biol Environ Stat 14:322-337. https://doi.org/10.1198/jabes.2009.08038

84. Rieger I (1979) Scent rubbing in carnivores. Carnivore 2:17-25

85. Rivas-Martínez S, Gandullo J, Serrada R, Allué J, Montero J, González J (1987) Mapa de series de vegetación de España y memoria. Publicaciones del Ministerio de Agricultura, Pesca y Alimentación, Madrid

86. Roddie G, Holland C, Stafford P, Wolfe A (2008) Contamination of fox hair with eggs of Toxocara canis. J Helminthol 82:293-296. https://doi.org/10.1017/S0022149X08996954

87. Rossi L, Interisano M, Deksne G, Pozio E (2019) The subnivium, a haven for Trichinella larvae in host carcasses. Int J Parasitol Parasites Wildl 8:229-233. https://doi.org/10.1016/j.ijppaw.2019.02.007

88. Sebastián-González E, Barbosa JM, Pérez-García JM, Morales-Reyes Z, Botella F, Olea PP, Mateo-Tomás P, Moleón M, Hiraldo F, Arrondo E, Donázar JA, Cortés-Avizanda A, Selva N, Lambertucci SA, Bhattacharjee A, Brewer A, Anadón JD, Abernethy E, Rhodes OE, Turner K, Beasley JC, DeVault TL, Ordiz A, Wikenros C, Zimmermann B, Wabakken P, Wilmers CC, Smith JA, Kendall CJ, Ogada D, Buechley ER, Frehner E, Allen ML, Wittmer HU, Butler JRA, Toit JT, Read J, Wilson D, Jerina K, Krofel M, Kostecke R, Inger R, Samson A, Naves-Alegre L, Sánchez-Zapata JA (2019) Scavenging in the Anthropocene: human impact drives vertebrate scavenger species richness at a global scale. Glob Change Biol 25:3005-3017. https://doi.org/10.1111/gcb.14708

89. Selva N, Jedrzejewska B, Jedrzejewski W, Wajrak A (2005) Factors affecting carcass use by a guild of scavengers in European temperate woodland. Can J Zool 83:1590-1601. https://doi.org/10.1139/z05-158

90. Sillero-Zubiri C, Macdonald D (1998) Scent-marking and territorial behaviour of Ethiopian wolves Canis simensis. J Zool 245:351-361. https://doi.org/10.1111/j.1469-7998.1998.tb00110.x

91. Stockmaier S, Stroeymeyt N, Shattuck EC, Hawley DM, Meyers LA, Bolnick DI (2021) Infectious diseases and social distancing in nature. Science 371:eabc8881. https://doi.org/10.1126/science.abc8881

92. Straub MH, Kelly TR, Rideout BA, Eng C, Wynne J, Braun J, Johnson CK (2015) Seroepidemiologic survey of potential pathogens in obligate and facultative scavenging avian species in California. PLoS One 10:e0143018. https://doi.org/10.1371/journal.pone.0143018

93. Teurlings IJM, Melis C, Skarpe C, Linnell JDC (2020) Lack of cascading effects of Eurasian lynx predation on roe deer to soil and plant nutrients. Diversity 12:352. https://doi.org/10.3390/d12090352

94. Tiwari R, Dhama K, Sharun K, Iqbal Yatoo M, Malik YS, Singh R, Michalak I, Sah R, Bonilla-Aldana DK, Rodriguez-Morales AJ (2020) COVID-19: animals, veterinary and zoonotic links. Vet Q 40:169-182. https://doi.org/10.1080/01652176.2020.1766725

95. Traversa D, Frangipane di Regalbono A, Di Cesare A, La Torre F, Drake J, Pietrobelli M (2014) Environmental contamination by canine geohelminths. Parasit Vectors 7:67. https://doi.org/10.1186/1756-3305-7-67

96. Truyen U, Müller T, Heidrich R, Tackmann K, Carmichael LE (1998) Survey on viral pathogens in wild red foxes (Vulpes vulpes) in Germany with emphasis on parvoviruses and analysis of a DNA sequence from a red fox parvovirus. Epidemiol Infect 121:433-440. https://doi.org/10.1017/s0950268898001319

97. Turchetto S, Obber F, Rossi L, D'Amelio S, Cavallero S, Poli A, Parisi F, Lanfranchi P, Ferrari N, Dellamaria D, Citterio CV (2020) Sarcoptic mange in wild Caprinae of the Alps: Could pathology help in filling the gaps in knowledge? Front Vet Sci 7:193. https://doi.org/10.3389/fvets.2020.00193

98. Turnbull PC, Lindeque PM, Le Roux J, Bennett AM, Parks SR (1998) Airborne movement of anthrax spores from carcass sites in the Etosha National Park, Namibia. J Appl Microbiol 84:667-676. https://doi.org/10.1046/j.1365-2672.1998.00394.x 
99. Turner WC, Kausrud KL, Krishnappa YS, Cromsigt JPGM, Ganz HH, Mapaure I, Cloete CC, Havarua Z, Küsters M, Getz WM, Stenseth NC (2014) Fatal attraction: vegetation responses to nutrient inputs attract herbivores to infectious anthrax carcass sites. Proc R Soc Lond [Biol] 281:20141785. https://doi.org/10.1098/rspb.2014.1785

100. Weinstein SB, Buck JC, Young HS (2018a) A landscape of disgust. Science 359:1213-1214. https://doi.org/10.1126/science.aas8694

101. Weinstein SB, Moura CW, Mendez JF, Lafferty KD (2018b) Fear of feces? Tradeoffs between disease risk and foraging drive animal activity around raccoon latrines. Oikos 127:927-934. https://doi.org/10.1111/oik.04866

102. Wilson DE, Mittermeier RA (2009) Handbook of the mammals of the world, vol 1. Carnivores. Lynx Edicions, Barcelona. https://doi.org/10.1108/09504121211233871

103. Wong G, Bi YH, Wang QH, Chen XW, Zhang ZG, Yao YG (2020) Zoonotic origins of human coronavirus 2019 (HCoV-19 / SARS-CoV-2): why is this work important? Zool Res 41:213-219. https://doi.org/10.24272/j.issn.2095-8137.2020.031

\section{Figures}

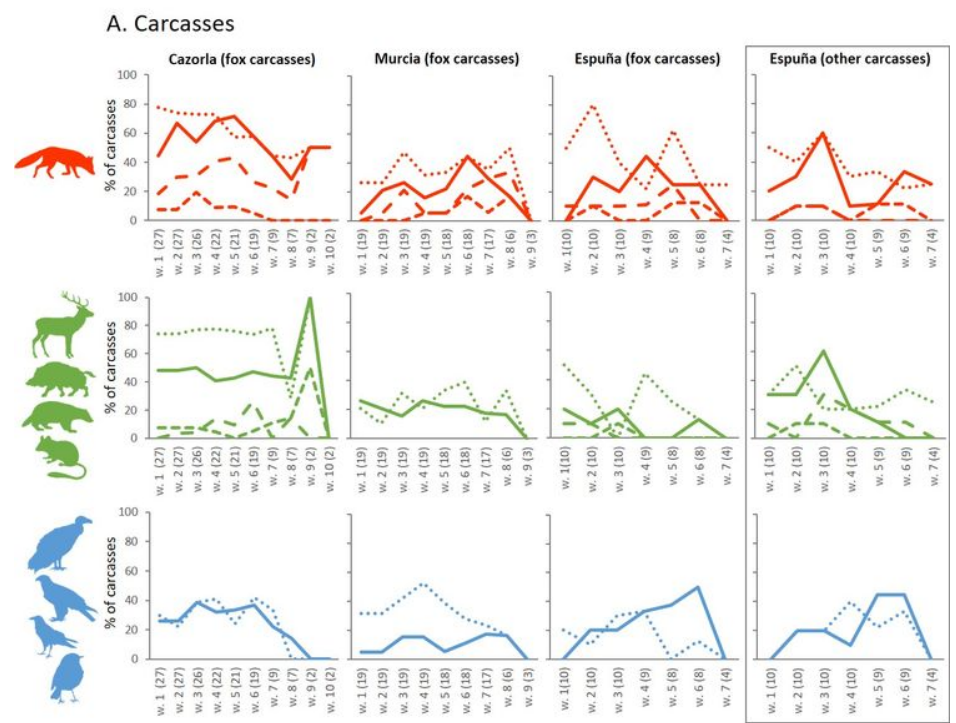

B. Events

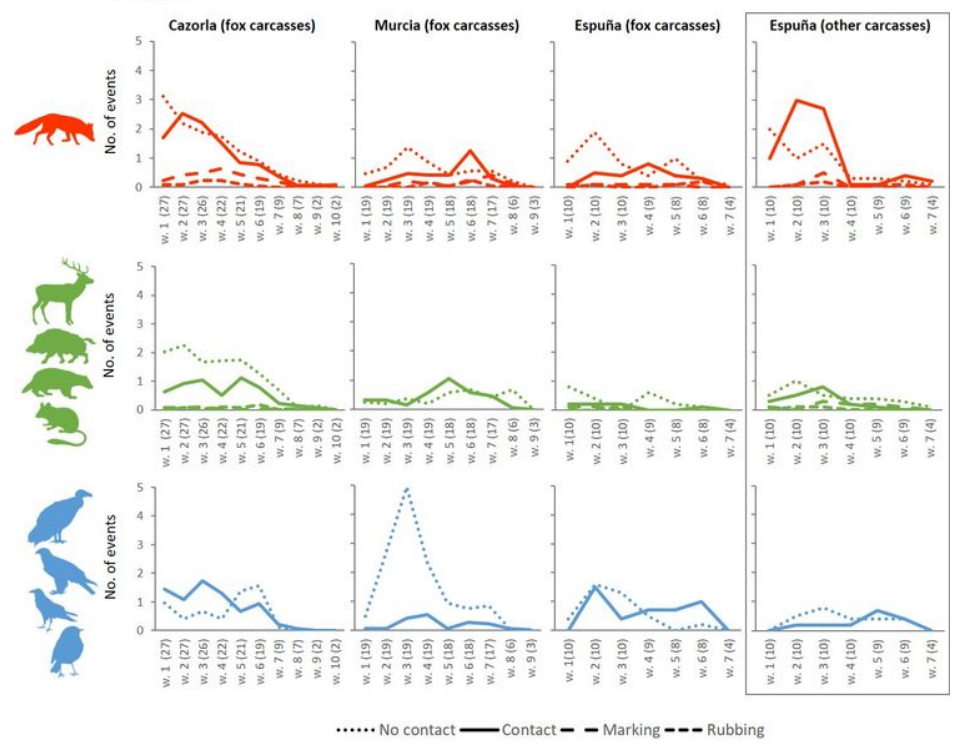

Figure 1

Weekly variation in patterns of use of mesocarnivore carcasses by red fox, other mammals and birds in three areas of southeastern Spain. A) Weekly percentage of contacted (i.e., with at least one contact event), non-contacted (i.e., visited, but no contact events recorded), marked (i.e., with at least one marking event), and rubbed (i.e., with at least one rubbing event) carcasses by red fox, other mammals and birds per study area and carcass type. B) Weekly number of contact, non-contact, marking, and rubbing events by red fox, other mammals and birds per study 
area and carcass type. For a given week, the number of events is divided by the total number of carcasses studied in each study area, and the number of carcasses available is given in parentheses. Panels for carcasses of carnivores other than foxes are in boxes.
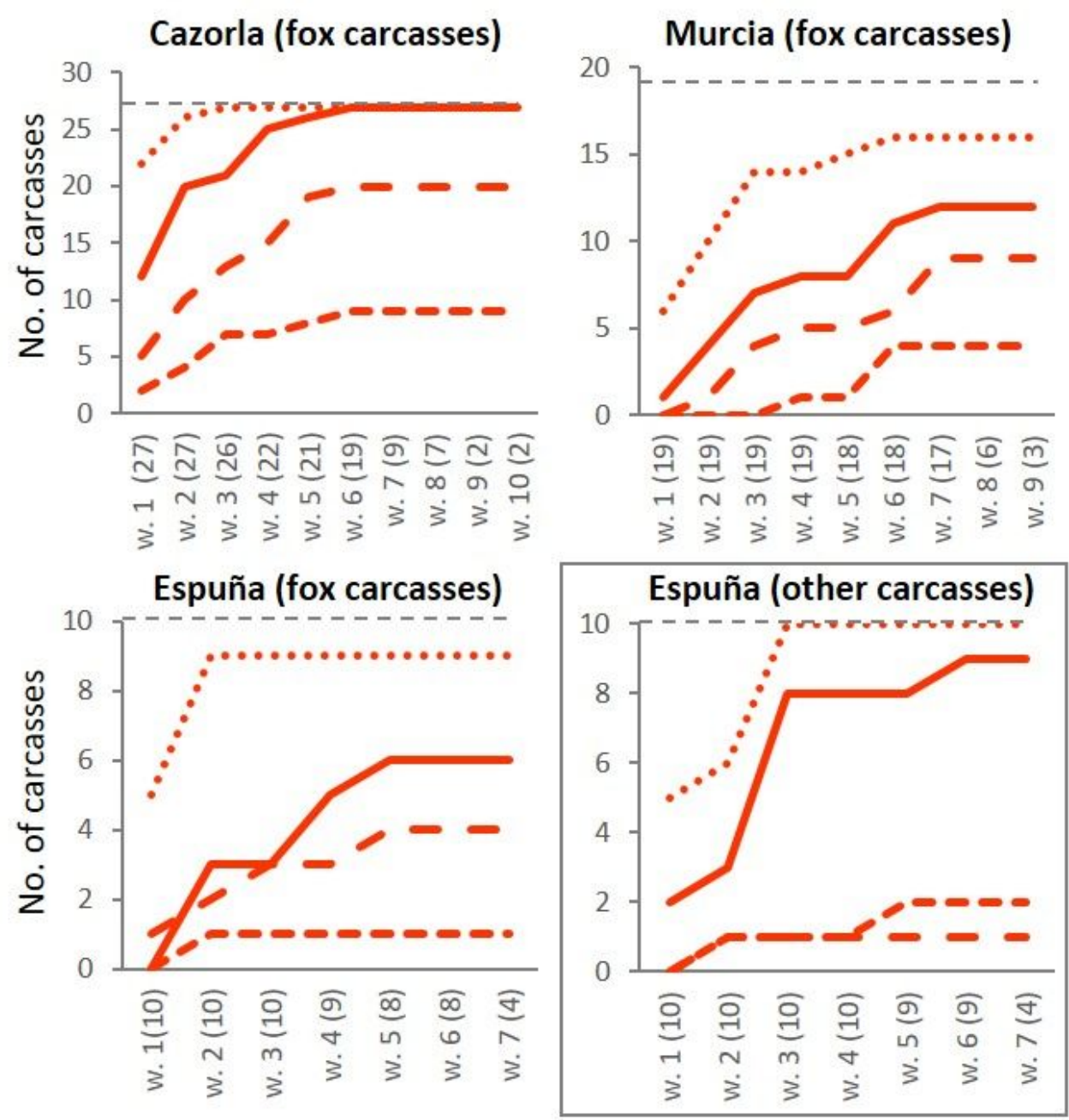

$\ldots \ldots$ Detected $\longrightarrow$ Contacted - Marked $-\infty$ Rubbed

\section{Figure 2}

Accumulated weekly number of detected (i.e., with at least one event recorded), contacted (i.e., with at least one contact event), marked (i.e., with at least one marking event), and rubbed (i.e., with at least one rubbing event) carcasses by the red fox per study area and carcass type. Dotted horizontal gray lines represent the accumulated number of available carcasses. For a given week, the number of carcasses available is given in parentheses. Panel for carcasses of carnivores other than foxes is in the box. 


\section{Cazorla (fox carcasses)}

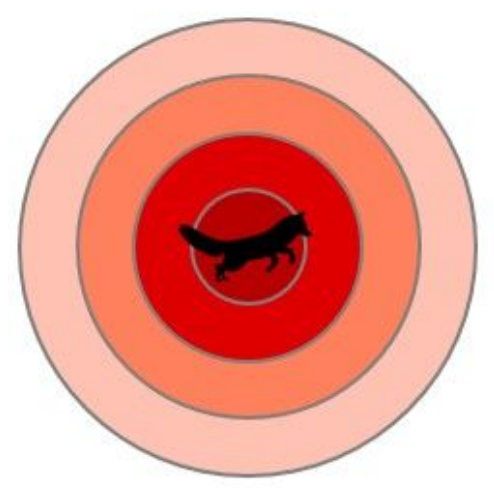

\section{Espuña (fox carcasses)}

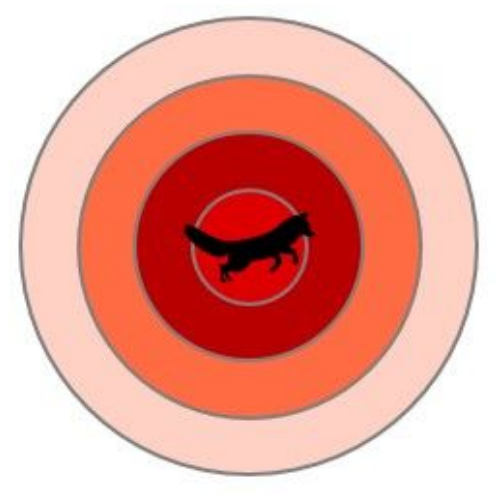

\section{Murcia (fox carcasses)}
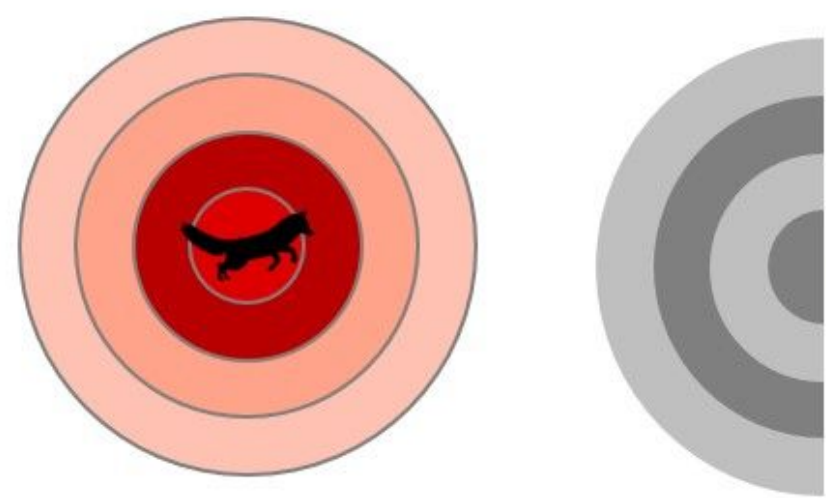

$>200 \mathrm{~cm}$

$>50-200 \mathrm{~cm}$

$>0-50 \mathrm{~cm}$

$0 \mathrm{~cm}$

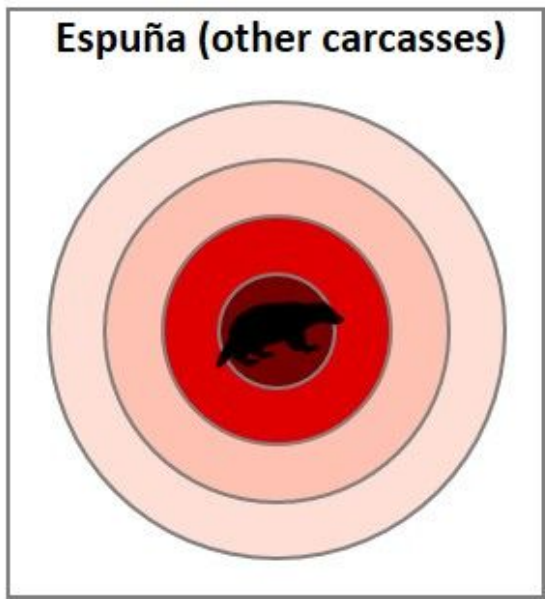

$0-10 \%$

$10-20 \%$

$20-30 \%$

$30-40 \%$

$50-60 \%$
$40-50 \%$

Figure 3

Minimum distance between visiting foxes and carcasses per study area and carcass type. Percentages are based on total events recorded per carcass type and study area.

\section{Supplementary Files}

This is a list of supplementary files associated with this preprint. Click to download.

- GonzalvezetalGraphicalabstract.jpg 